\title{
Besinning oor die apostolaat in die Nederduitsch Hervormde Kerk
}

\author{
H G van der Westhuizen \\ Hervormde Teologiese Opleiding
}

\begin{abstract}
A considering on the apostolate of the Nederduitsch Hervormde Church
\end{abstract}

In spite of spending large sums on missions, the Nederduitsch Hervormde Kerk van Afrika needs to rethink the organisation of its mission councils. A plea is made for fundamental reorientation at membership level in both the Nederduitsch Hervormde Kerk van Afrika as the 'missionary church' and the Hervormde Kerk in Suidelike Afrika as the 'mission church' in respect of their mission structures.

\section{VOORAF}

'n Verskeidenheid belangstellings in die teologie kenmerk Petrus Johannes Theobaltus Koekemoer. Dink onder andere aan sy artikels oor die Bybelse argeologie, artikels en publikasies op die terrein van die etiek soos byvoorbeeld oor selfmoord, eutanasie, stenwensbegeleiding, aborsie, padverkeer en so meer. Professioneel is hy formeel dogmatikus. Nogtans het hy, behalwe 'n besondere aanvoeling vir die pastoraat - waar gaan jy 'n beter sieketrooster, krisisbegeleier en vriend vind? - ook 'n besondere interesse vir die apostolaat. Dit is op laasgenoemde terrein dat ons vir meer as twee dekades reeds in die Sendingraad saam gewerk het. Bybelverspreiding, 'n saak waaraan hy as voorsitter van die betrokke kerklike raad, langdurige en noukeurige aandag gegee het, moet ook teen die agtergrond van die apostolaat verstaan word. Omdat hy ook reeds in sy proefskrif die Rooms-Katolisisme aanvat, was sy Bybelverspreiding en ander apostolaatsbemoeienis steeds akuut reformatories. Tiperend hiervan kan die afskeidsboodskap van student $A$ M Letshabo aan die einde van 1987 genoem word. Toe hy namens die studente wat afstudeer 'n woord spreek, het hy van prof dr Koekemoer onder andere gesê dat die heel eerste dogmatieklesing só begin het: Dumêlang barêna! Sola Scriptura.... 
Aangesien ons nou vir meer as 'n dekade, sedert 1 Januarie 1979, in die Hervormde Teologiese Opleiding baie soet en suur, selfs baie gevare saam beleef het, wil ek met hierdie besinning oor ons gemeenskaplike arbeidsveld die alomgeliefde oom Theo, groot Van Ruler student, dankbaar vermeld.

\section{INLEIDING}

Die wese van die kerk van die Here is die Heer van die kerk. Die kerk is die aardse liggaam van Jesus Christus, wat sy hemelse hoof is. Die kerk is Christelike kerk of dit is nie kerk nie. Omdat Christus die wese van die kerk is, is die wesenskarakter van die kerk tweeledig: die dissipelmatige en die apostolaat. Van uit die wese en wesenskarakter van die kerk belig die Bybel 'n drieërlei wesensfunksie van die kerk. In hoofsake is die apostolaat 'n profetiese funksie, terwyl die pastoraat 'n koninklike en die diakonaat 'n priesterlike funksie is. Die pastoraat word huidig sterk deur Kital ondersteun. As Kerklike Instituut vir die Toerusting van Ampsdraers en Lidmate, verrig Kital deur navorsing, publikasies, kursusse en selfs skakeling met die Departement Praktiese Teologie aan die Universiteit van Pretoria 'n groot diens. So het die Kerk se kategese byvoorbeeld al enorme aandag geniet. Die diakonaat is huidig baie aktief en word deeglik gekoördineer deur die Sekretaris vir die Barmhartigheidsdiens. Diensgroepe byvoorbeeld kry beslag. Wat die apostolaat betref, kry 'n mens die gevoel dat, hoewel daar baie geld aan byvoorbeeld die totale sendingprojek gespandeer word, die apostolaat in geheel te ongekoordineerd is en veel meer vaartbelyn en effektief beoefen moet word. So 'n onderneming sou ook in pas wees met die Kerk se 1986-besluit rondom die tema kerk en wêreld 2000.

Kyk 'n mens na die 1989 Kerkwet, bepalings 42 tot 54 , dan is die vernaamste elemente vir die beoefening van die apostolaat soos in Artikel IX geformuleer en hieronder aangehaal, aanwesig. Kom ons egter by die praktyk van die Kerk, word bemerk dat die apostolaatselemente soos los donkies by die kerklike werf rondwei, maar nie ingespan is om werklik saam te trek as ordelik gegroepeerde komponente om sodoende die Kerk optimaal effektief te mobiliseer vir sy apostolaatsfunksie nie.

Die Kerkwet artikel IX lui soos volg:

\section{Apostolaat van die Kerk}

1. In die verwagting van die koninkryk van God, met die volmag van Jesus Christus die Here aan wie alle mag in hemel en op aarde behoort, en in gehoorsaamheid aan sy bevel: 'Gaan dan na al die nasies toe en maak die mense my dissipels: doop hulle in die Naam 
van die Vader en die Seun en die Heilige Gees, en leer hulle om alles te onderhou wat Ek julle beveel het' (Matt 28:19, 20), vervul die Kerk sy apostoliese opdrag deur

\section{Bybelverspreiding,}

sending onder alle volke, arbeid onder die Moslems, getuienis teenoor die Jode, arbeid onder diegene wat van die evangelie vervreem is, en die voortdurende evangelisering en hervorming van die volkslewe.

2. Die Kerk rig hom in die sending tot bevolkingsgroepe of gemeenskappe in Afrika wat nog heidens of gedeeltelik heidens is, om hulle te help met die verspreiding van die evangelie in hulle eie gemeenskappe en kerstening van hulle gemeenskapslewe, en deur diegene wat deur daardie diens tot geloof gekom het, by te staan by die inrigting en opbou van 'n eie kerklike lewe sodat hulle uiteindelik tot afsonderlike selfstandige kerk(e) kom.

3. Die Kerk getuig teenoor die Jode dat die God wat Hom aan Israel geopenbaar het die Vader van Jesus Christus is, en dat Jesus Christus die Verlosser is in wie al die beloftes van God bevestig is (2 Kor 1:20).

4. Die Kerk roep diegene wat van die evangelie vervreem is, tot bekering en betuig teenoor owerheid en volk die heerskappy van God op elke terrein van die samelewing en die eis dat die samelewing ingerig word volgens die beloftes en die wil van God.

(NHKA 1989:3-4)

Die Kerk het 'n aantal apostolaatselemente wat sonder radikale struktuurveranderings van bestaande instrumente tog ingrypend tot komponente van 'n eenheidsapostolaatsfunksie gesmee kan word. Die elemente is onder andere:

- Voortdurende kerstening van die volkslewe;

- Sending onder alle volke;

- Evangelisasie van kerkvervreemdes; 
- Getuienis teenoor die Jode;

- Arbeid onder die Moslems;

- Hervorming van Rooms-Katolieke;

- Herwinning van leerdwalendes;

- Bybelverspreiding en kolportasie.

Elkeen van hierdie afdelings het onderafdelings. Sending sluit byvoorbeeld die saak van opleiding van leraars en sendingwerkers in. Arbeid onder Moslems veronderstel die studie van die Islam, en ook ander godsdienste soos noodsaaklik blyk te wees. Getuienis teenoor die Jode is nie net 'n voortdurende en grondige studie van die situasie van die Jode nie, maar daadwerklike beplanning en uitvoering op alle moontlike maniere van hierdie getuienis. Evangelisasie weer, oorvleuel met sending byvoorbeeld in die sin dat ook die sendingkerk soos elke kerk, heel gou met die probleem van kerklosheid sit. Aan die ander kant het ons in die situasie van die gevestigde kerk soms te make met 'n kerklosheid wat volledig 'n kerkloosheid, 'n totale kerkvervreemdheid en gesekulariseerdheid openbaar. Dan is dit nie meer verbondsbreuk wat deur die pastoraat bediening verg nie, maar suiwer evangelisasie van vooraf. Ook immigrante wat volkskerklik by ons kan aanpas maar totaal kerkloos is, is 'n missionerre evangelisasieterrein. Indien hulle nog 'n kerklike verbintenis het, ressorteer hulle onder die pastoraat. Die voortdurende kerstening van die volkslewe, sluit ook getuienis van die kerk teenoor die owerheid en volk in.

Omdat die getuienis teenoor die owerheid en volk ook 'n spesifieke uitvloeisel van ons volkskerkgedagte is, moet ons sorg dra dat die volkskerk ook in die ander elemente karaktergewend van alle arbeid sal wees. Daarom is koördinering ook in hierdie opsig noodsaaklik. Andersins sou die situasie kan ontstaan dat die sending met die volkskerkgedagte werk en byvoorbeeld die Moslemarbeid met 'n vrye kerk gedagte!

\section{AANPASSING VAN BESTAANDE STRUKTURE}

\section{Sentrale raad vir die apostolaat (Sera)}

Sinodaal is ook die apostolaat reeds met rade gestruktureer. Hierdie bestaande rade kan uitgebrei, aangepas en gekoördineer word in 'n sentrale raad. Sera kan byvoorbeeld saamgestel word uit twee of 'n paar lede van elk van die verskillende rade. Anders as 'n apostolaatwerkgroep wat hoofsaaklik net rapporte opstel, moet Sera werk. 
Indien die apostolaatsrade nie onafhanklik paradeer nie, sal hulle saamgebind word tot gelyke aksie. Sera behoort te sorg dat die een raad nie die pas markeer terwyl 'n ander raad reeds die dodemars marsjeer en 'n derde 'n aanvalsmars lanseer nie.

Daarby behoort denkenergie en groeipynenergie nie gedupliseer en verspil te word nie. Wat die raad vir evangelisasie bedink en geimplimenteer het en wat goed werk en goedskiks deels benut kan word deur die sendingraad, hoef nie toevallig eendag ook deur die sendingraad eers uitgedink te word nie. Wat in die sendingraad goed funksioneer, kan dalk ook profytlik deur die raad vir die verkondiging aan ander godsdienstiges benut word, en so meer.

Die denke oor die algemene apostolaat kan deur Sera geweldig gestimuleer word en 'n rykdom inisiatiewe kan aldus ontstaan. Die kanalisering tussen Sera en die onderskeie rade kan 'n katalisator in Kital verkry.

Kerklike Instituut vir die Toerusting van Ampsdraers en Lidmate (Kital)

Behalwe dat Kital vir die pastoraat en die diakonaat benut word, kan die huidige tendens wat daar reeds bestaan, volledig uitgebou word om Kital ook vir die apostolaat te benut. Dit is wat onder Sinto bepleit word (Van der Westhuizen 1978:3).

Daar hoef dan nie 'n Sendinginstituut gestig te word vir navorsing, toerusting en opleiding (Sinto) nie. In plaas dat so 'n veronderstelde Sinto miskien eensydig net aan die missionêre aandag gee, kan die hele apostolaat deur Kital ondersteun word (vgl Notule, Algemene Kerkvergadering NHKA 1986:221, punt 6.3.5.4, vierde asterisk).

Omdat Kital 'n praktiese diensfunksie van navorsing, toerusting en opleiding bied en nie 'n selfstandige of selfbeskikkingsposisie moet he nie, kan dit 'n plek inneem in die bestaande strukture van die Kerk. Omdat die geskiedenis in byvoorbeeld Duitsland getoon het dat 'n instituut in die kerk soos 'n vreemde liggaam bly wat mettertyd selfs teenoor die kerk te staan kan kom, sou die kerklike gestruktureerdheid van Kital in die moontlike breëre nuwe opset groter ontspanning en aanvaarding in die Kerk meebring.

Miskien kan Kital 'n breëre diensfunksie, ingebed in die bestaande strukture van die Kerk, inneem, deurdat sy direkteure, uitgebrei om ook die apostolaat te bedien, lede van die onderskeie rade moet wees.

\section{Taakomatrywing}

Die presiese taakomskrywing van Sinto, of Kital waarby Sinto ingeskakel is, kan via die Instituut self aanvanklik gedoen word. Dit sal ook algaande altyd verbeter en 
verfyn moet word. Voorlopig kan slegs hooflyne getrek word met die oog op implementering van so 'n Instituut.

\section{Navorsing}

Die Instituut moet in staat wees om 'n omvattende biblioteek op te bou. Omdat Kital reeds oor 'n ekumeniese biblioteek beskik en oor die kennis en vaardigheid van biblioteekhantering, mikro-fich en die ontsluitingstegnieke, kan die biblioteekgeriewe van Hervormde Teologiese Opleiding by Klipdrif hiermee gesinchroniseer en uitgebou word.

Saam met die uitbou van 'n biblioteek gaan die versameling van alle sendingmatige inligting. Hier kan spesifiek gedink word aan verdere prinsipiële navorsing oor sending, sending vandag, sending in die wëreld van die jaar 2000 , sending in ons land, sending in ons buurlande, sending in verafgeleë lande, sending in kommunistiese lande, in Moslemlande, in lande waar die voorvaderaanroeping of tradisionele godsdienste herleef, en so meer. Hoe die kerklike eiendomme in byvoorbeeld Namibië en Zimbabwe sendingmatig benut kan word, moet oorweeg word. Sending onder trekarbeiders moet ondersoek word.

Besondere aandag moet nog omvattend gegee word aan die uitgangspunte van die Nederduitsch Hervormde Kerk se eie volkskerklike sendingbeleid. Is sy metodes in ooreenstemming met sy beleid? Is sy modelle bytyds? Wat is die plek byvoorbeeld van die barmhartigheidsdiens (vgl Notule, Algemene Kerkvergadering NHKA 1986:220, punt 6.3.4.8)?

Ook historiese navorsing en versameling van gegewens ten opsigte van stof wat by ringsuperintendente lê, moet georden word. Baie inligting kan op die sendingterrein van ons Kerk opgespoor word, indien die swart leraars programmaties daarvoor spesifiek ingespan word.

Nie net veral oor ons sendingaanvang in Zululand nie, maar ook besonderhede van ons Kerk se missionére teenwoordigheid vroeër in Wes-Afrika, Oos-Afrika, Suidwes-Afrika, Zambiě, Zimbabwe en so meer, moet op rekord geplaas word.

Ten opsigte van sendingbeleid en sendingmetode moet die inhoud en aantreklikheid van die onafhanklike kerke bestudeer word: ook byvoorbeeld die 'Church Growth' van MacGavran. 'n Besondere afdeling van kerkgroepe wat miljoene aanhangers of lidmate het, genaamd Reformed Independent Churches Association (RICA) skakel al geruime tyd met ons. Hier is dus ' $n$ afdeling nie alleen vir grondige navorsing nie, maar waaroor ook beplan en aan wie bystand verleen kan word. Omdat Kital op die ekumeniese vlak reeds 'n hand aan RICA het, en omdat die Sendingraad huidig alleen en voluit by die Hervormde Kerk in Suidelike Afrika betrokke is, sou dit goed wees indien die Sendingraad die Instituut en Sera as 
buffers kan gebruik. Hiermee sou ook 'n komponent van die Nederduitsch Hervormde Kerk se toekomsprojek Kerk en wereld 2000 (1985:86) voortgang geniet.

Navorsing oor die wetenskaplike bepaling, opstelling en afhandeling van prioriteitslyste is ook dringend nodig.

Hoe lank onderneem die Nederduitsch Hervormde Kerk nie al van tyd tot tyd ondersoekstudies na sending onder die Kaapse Kleurlinge nie. Aan die een kant tel téen so 'n sending die feit dat $87 \%$ Kleurlinge reeds Christene is (in vergelyking met 91,8\% Blankes). Aan die ander kant moet die probleem dat daar wel 'n behoefte by Kleurlinge aan die Hervormde Kerk geïdentifiseer word, aangespreek word. Andersins sou hulle opname in die Kerk se gemeentes, veral in die Kaap, akuut word.

Die Nederduitsch Hervormde Kerk se sendingbeleid en Artikel III van die Kerkwet kan 'n dringende navorsingsveld in die huidige politieke verwikkelinge word.

Alles wat die Hervormde Kerk en Hervormdes oor kerstening geskryf het, moet versamel, gesistematiseer, geïndekseer, bewaar en vir navorsing toeganklik gestel word en nagevors word.

Die Kerk het onlangs ook besluit dat aandag aan sending onder trekarbeiders gegee moet word. Waar begin jy prakties om so 'n opdrag uit te voer? Die superintendent en ringsrade kan moeilik sommer begin. Dit lêt nie op die weg van die Hervormde Teologiese Opleiding as akademiese instelling om 'n beginpunt te identifiseer nie. 'n Instituut kan egter onmiddellik navorsing oor die saak loods en op grond van sy bevindinge kan dan met handeling begin word.

In die verband van Artikel III van die Kerkwet en veral die trekarbeiders, is navorsing en veral beplanning ten opsigte van verstedeliking van die uiterste belang. Aangesien instromingsbeheer opgehef is - en Blankes grootliks reeds klaar verstedelik is - sal swart verstedeliking dié groot maatskaplike verskynsel van ons toekoms op die pad na die jaar 2000 wees (Departement s a:3, punt 3.3).

Navorsing en beplanning met die oog op die Hervormde Kerk se volkskerklike sendingbeleid, gesien teen die agtergrond van die Kerk se standpunt van 'afsonderlike en gelyke geleenthede vir alle volke as bevolkingsgroepe' (Moderamen 1986:5), kom in 'n ernstige lig, gesien die verstedelikingstrategie. Op 'n paar sake as voorbeelde moet in hierdie verband gewys word.

Eerstens moet gelet word op die geweldige omvang van swart verstedeliking wat nou voor die deur staan. Daarby kom die tendens dat Swartes nie net in swart gebiede gevestig gaan word nie. 'Vestiging van Swartmense in nie-Swart dele van dorpe en stede is onderworpe aan bestaande owerheidstoestemming en kontrole' (Departement s a:22, punt 5.3.1.7). 'Kennis moet geneem word van die verwantskap tussen grondgebruik- en vervoerbeplanning, met die oog daarop om woon- en werk- 
plekke waar moontlik naby mekaar te plaas om sodoende reisafstande en reistye te verkort' (Departement s a:29, punt 6.11.5). 'Die uitgangspunt van hierdie Artikel (Art 9 van Wet 25 van 1945: Afsondering van Swartes in stadsgebiede) is dat Swartmense met sekere uitsonderinge nie in Blanke gebied mag bly nie....Aangesien hierdie maatrekl by uitnemendheid teen Swartmense diskrimineer, sal dit geskrap word' (Departement s a:65, punt 2.1.6).

Tweedens word beklemtoon dat die verstedeliking maatskaplik-kerklike vereistes van groot omvang gaan stel: 'Die regering is oortuig daarvan dat die dienste op maatskaplike gebied onder groter druk sal kom namate verstedeliking toeneem' (Departement s a:45, punt 11.3.2). Die staat se: 'Met alle nuwe dorpsvestiging moet gemeenskapsbinding uit die staanspoor bevorder word' (Departement s a:44, punt 11.2.7; vgl ook punt 11.2.1, punt 11.2.2, punt 11.3.1 en andere). Moet die Kerk dan nie ook betyds sy strategie met die oog op sending uitwerk nie (vgl Notule, Algemene Kerkvergadering 1986:221, punt 6.3.5.4)?

Verdere navorsingsterreine sal ook onder ander punte hierna aan die orde kom. Dit moet in gedagte gehou word dat die Instituut se navorsing nie alleen by hom berus nie, maar dat hy die inisiatief en organisering daarvan kan opneem om saam met die Departement Godsdiens- en Sendingwetenskap van die Fakulteit Teologie (Afd A) by die Universiteit Pretoria, die Hervormde Teologiese Opleiding en ander instansies (soos sendinginstitute van ander kerke of universiteite) te werk.

\section{Toerusting}

Terwyl Kital reeds in 1987 die eerste kursus gereël het om ringsuperintendente van sending toe te rus vir hulle taak, sou die uitgebreide Instituut, sonder om die eiesoortigheid van elke sendingprojek te integreer met die Hervormde Kerk se eie toerusting, gedifferensieerde toerustingsprojekte kan loods. Jare vo6r die ontstaan van Kital is wat hy nou deels doen onder die naam Sinto bepleit.

Gesien die lewenspeil van die Hervormde Kerk in Suidelike Afrika (HKSA) se arbeidsterrein, sal as deel van toerusting ook vir 'n lang tyd toesig bedoel word. Weer eens kan die bestaande struktuur van superintendente en ringsrade benut word. Die gesofistikeerde en begeleide toerusting van die Instituut as diensfunksie behoort net dié effektiwiteit aansienlik te verhoog.

Nie alleen voortgesette toerusting van studente en afgestudeerde leraars en evangeliste is nodig nie, maar ouderlinge en diakens funksioneer huidig hoegenaamd nie naastenby soos die Bybel dit vereis nie. Groepe ampsdraers, veral ook skribas, kassiere, kategete, kerklike verenigings (susters, jeug), moet dringend voorligting, toerusting en begeleiding deur kundige toegeruste mense ontvang. Hierdie saak is ernstig, veral omdat leraars nie voldoende aandag hieraan gee nie. 
Soms is hulle selfs teen voorligting gekant:

Die Kommissie van die Algemene Kerkvergadering (HKSA) bet oorcengekom ( = saamgestem - H G vd W) dat daar nog predikante is wat die kerkraadslede doelbewus onkundig hou sodat bulle optrede nie... raakgesien kan word nie.

Aanbeveling Ouderlinge op ringsvlak moet beter opgelei word om so beter toegerus te word vir die amp.

Goedgekeur. (Derde Algemene Kerkvergadering HKSA 1985:31. Vergelyk ook bl 32 waar besluit is dat daar ook 'diaken- en diakonesse-kursusse' moet wees).

Die ontwikkeling van inheemse kerksang, die waarde, beskikbaarheid en benutting van literatuur, film en al hierdie toerustingsmiddele wat veral vir die swart gemeenskap van ontsaglike waarde is, le nog onbenut. Die Nederduitsch Hervormde Kerk van Afrika (NHKA) se besluit dat die Hervormde Teologiese Opleiding deur middel van veral publikasies die teologie in die HKSA moet bevorder, sou hierdeur sterk ondersteun kan word. Kital is reeds in die publikasieproses vir die NHKA volledig betrokke.

Die Instituut moet 'n struktuur opbou waar inligtende en toerustende gesprekke gevoer kan word byvoorbeeld oor teologiebevordering, publikasies, vertalingsdiens, Bybelstudie, kursusse en so meer (vgl Notule, Algemene Kerkvergadering NHKA 1986:218/9, punt 6.3.1.2.1 en 6.3.2.1).

Algaande moet die kerke wat uit die Hervormde Kerk se sending ontstaan of reeds deur die Hervormde Kerk gehelp word, ook administratiewe infrastruktuur opbou. Hierdie toenusting, ook vir volledige toekomstige kerkkantoorpersoneel van selfstandige kerke, moet aandag ontvang.

Die feit is dat die Hervormde Teologiese Opleiding wat probeer om sommige van hierdie aspekte te dek, asook die ringsrade, nie by magte is om sonder die nodige skakels, wat juis deur 'n instituut voorsien kan word, na wense te funksioneer nie.

\section{Opleiding}

Omdat die HTO reeds gevestig is, hoef ons hier nie breedvoerig oor opleiding te handel nie. Hier is die wiele reeds aan die rol. Bepaalde strukture moet egter opgerig word sodat dosente die leefwereld, -probleme en kerkbehoeftes van die HKSA beter leer ken, soos byvoorbeeld om in rotasie die Superintendent vir 
Sending te vergesel op sy amptelike besoeke binne die ressort van die HKSA. Die heroorweging van 'n evangelistediens, die opleiding van vroue-leraars (vgl Notule, Derde Algemene Kerkvergadering HKSA 1985:9), die verinheemsing en relevantmaking van die Opleiding moet dringend aandag kry.

Daar sal waarskynlik, nadat reeds bestaande literatuur oor die impak en waarde van indiensopleiding in die Derde Wereld nagevors is, ook met die tipe opleiding begin moet word. Dit sluit behalwe indiensopleiding ook deeltydse diensopleiding in. Hier le 'n groot en vrugbare braakveld wat ondersoek moet word, gefundeer op die sogenaamde 'tentmakersberoep' van die Bybel.

Verder moet onthou word dat die HTO nie sy akademiese vrug voldoende kan lewer in die gestalte van byvoorbeeld publikasie ten dienste van die teologie in die HKSA nie, as hy nie aan die een kant deur die uitsortering van bykomende verplig. ting van praktiese aard die tyd daartoe gegun word nie, en aan die ander kant deur allerlei tegniese en ander hulp soos die Instituut kan bied, ondersteun word nie. Hier kan byvoorbeeld gedink word aan vertalingsprojekte, studie van die Swart lewensfilosofie, lewens- en wêreldbeskouing, taal en so meer.

\section{Raad van evangelisasie van volksgenote (Rev)}

Op drie fasette moet die aandag gevestig word: Kerklosheid, buitekerklikheid en sekularisasie.

\section{Kerllosheid}

Die proses van sekularisasie, en watter ander faktore daar ook mag wees, wat bydra tot die uiteindelike vorming van 'n heidendom te midde van 'n eens Christelike volk of gemeenskap, het 'n binnekerklike effek. Kerklosheid is gewoonlik een van die eerste simptome van hierdie siekte. Die simptoom word nog ernstiger wanneer kerklosheid corskuif na 'n praktiese kerkloosheid. Maar vir sover betrokke persone teoreties nog lidmate van die kerk is, ressorteer hierdie hele probleem onder die pastoraat van die kerk - en alles wat daarmee saamgaan.

Dit is nie in die eerste plek Rev se taak om kerklosheid te hanteer nie. Die pastoraat moet besin oor voorkoming, behandeling en beëindiging waar moontlik van die probleem. Dit sal sekerlik sake op die tafel bring soos effektiewe prediking. kategese, besondere kategese, huisbesoek, tug, studies oor media-invloed, geestestromings van die tyd en so meer.

\section{Buitekertlikheid}

Wanneer persone prakties nie meer lidmate van die kerk is nie, is hulle inderdaad buite die kerk en behoort hulle amptelike lidmaatskap ook beëindig te word - indien 
die pastoraat bulle nie meer effektief bereik nie. Kerklosheid het dan in kerkloosheid oorgegaan.

Die taak van Rev neem by hierdie oorgangsgebied sy aanvang. Daar is dus 'n bepaalde gemeenskaplike studieveld tussen die pastoraat wat handel met die probleem van kerklosheid en Rev wat handel met die probleem van kerkloosheid.

Die studie wat die Hervormde Kerk reeds oor die loop van jare in verband met hierdie probleem gedoen het, moet gesistematiseer en ontsluit word. Die ter saaklike punte, metodes en planne van hierdie reeds gedane en voortgesette studie moet voortdurend soos benodig word van Rev af tot by die kerkrade en gemeentelede deurvloei.

Nie alleen is Kital se publikasievoorsiening ook in hierdie verband noodsaaklik nie, maar die professionele diens wat die Instituut kan lewer by die toerusting van gemeentelike evangelisasieprogramme, is 'n langdurige en gespesialiseerde verantwoordelikheid.

\section{Sekularisasie}

In 'n sekere sin sluit sekularisasie sowel buitekerklikheid as kerklosheid in. Maar met sekularisasie moet die aandag op die groter wordende taak gevestig word van 'jong' sendingvelde. Die kerk praat baie maal van die jong kerke, verwysende dan na sendingkerke of kerke wat uit sendingwerk ontstaan het. Die aandag moet dringend gevestig word op wat genoem kan word die jong sendingveld. En dit is die stolling van kerklosheid, kerkloosheid en buitekerklikheid in 'n totale nuwe heidendom. Hierdie heidendom is iets anders as 'n oorspronklike heidendom. Hier het ons te doen met die verwerping van Christus en nog meer - dalk met die verwerping deur God.

Hierdie verskynsel is natuurlik in Europa en ander gebiede al 'n ou bekende probleem. Daarom is die neiging in hierdie lande se kerke om nie meer onderskeid te maak tussen evangelisasie en sending nie. Die gesekulariseerde wêreld is 'n Vierde Wereld wat in ons midde en op ons drumpels verskyn. Dis 'n nuwe wereld die jong sendingveld.

Woorde soos sending en evangelisasie beteken wat die gebruiker daarmee bedoel. Terwyl die woord apostolaat die totale wereldgerigtheid van die kerk bedoel, bedoel die kerk met sending en evangelisasie gewoonlik net een of ander komponent van die apostolaat. Tussen die twee woorde het evangelisasie 'n vaster betekenis as sending. Omdat evangelisasie ' $n$ woord uit die Bybel is, dra dit altyd die betekenis van die oorbring van die evangelie aan mense. Sending word dikwels so breed opgevat dat dit soms neig om 'n sinoniem vir apostolaat en selfs meer as apostolaat te word. Onder sending is soms selfs kultuuroordrag, politieke oordrag, 
algemene ontwikkelingshulp, skole en hospitale en so meer bedoel. Die Nederduitsch Hervormde Kerk van Afrika het daarom soms van die woord sending gesku en in die plek daarvan ander woorde soos evangelisasie, kerstening en so meer gebruik.

Omdat onder sending en evangelisasie dit verstaan word wat die spesifieke kerk, kerke of tydsgees bedoel, is dit nodig dat ons vandag weer noukeurig na die woorde as begripsterminologie moet kyk om te bepaal wat ons daaronder verstaan en wat die verhouding van die spesifieke twee tot mekaar is.

Evangelisasie as evangeliekommunikasie kan objektief veral drie betekenisse dra: die verkondiging van die evangelie in die kerk, die verkondiging van die evangelie aan heidene wat nog nooit aan die kerk behoort het nie, en die verkondiging van die evangelie aan hulle wat in die kerk was en nie meer is nie en nou teruggeroep moet word.

Om laasgenoemde van die ander komponente van die apostolaat te onderskei, het die kerk veral in Duitsland, Nederland en Suid-Afrika die woord evangelisasie gebruik.

Aan die begin van die 19de eeu het evangelisasie in Duitsland onder die 'gedoopte heidene' begin. Die beskrywing van die onderskeid tussen evangelisasie en sending is toe met die uitdrukkings inheemse sending en uitheemse sending aangedui (Wiersinga 1977:674-678). Ook hierdie begrippe het die Hervormde Kerk in sy sendinggeskiedenis só gebruik.

Wichern (1808-1881) was in Duitsland die voorloper om inwendige of inheemse sending uit te brei na kerklik-evangeliese bystand in die maatskaplike en sedelike nood van die eie volk. Onder evangelisasie of inheemse sending is twee dinge veral beklemtoon: die algemene priesterskap van die gelowiges en dat gelowiges nie net geloof het nie, maar ook liefde.

In Nederland het Otto Gerhard Heldring (1804-1876) die voortou met inheemse sending geneem. F W Grosheide het in die veertigerjare van ons eeu evangelisasie baie duidelik gedefinieer as die verkondiging van die evangelie aan gewese verbondskinders en sending as die verkondiging aan die moontlike toekomstige verbondskinders.

Die Nederlandse Hervormde Kerk het na die Tweede Wereldoorlog baie sterk klem op die kerk se verantwoordelikheid teenoor die ontkerstende deel van die volk gele. Tewens daar was 'n hele apostolaatsherlewing in die Nederlandse Hervormde teologie.

In Suid-Afrika het ons in die Nederduitsch Hervormde Kerk die koers van evangelisasie as die evangelieverkondiging onder ons Afrikanervolksgenote voortgesit. Dit is 'n voortsetting van die gedagte van die kerklike bearbeiding van 
gedoopte heidene: mense wat nie meer aan die kerk behoort nie. Omdat ons 'n Christelike volk geag is, is almal in die volk wat nie aan die kerk behoort nie as gewese kerkmense beskou. Die sekularisasieproses as ontkersteningsproses het in ons volk egter ook reeds sulke afmetings aangeneem dat daar nie meer net die 'verlore seuns' in ons volk is nie, maar ook hulle kinders en kleinkinders - soos prof F J van Zyl dikwels sê.

Dat evangelisasie op hierdie blanke heidendom in ons eie volk gerig moet wees, blyk duidelik uit ons huidige konsep-Kerkwet bepaling 7.3(4?) en reglement 6.2. Reglement 6.2.1.2 bepaal dat die Raad vir Evangelisasie onder andere die beginsels vir die evangelisasiewerk bepaal en planne beraam om nie-gelowiges en buitekerklikes te bereik. Die evangelisasiewerk val dus onder die apostolaat, maar teen die tradisionele agtergrond word daarmee nie die evangelieverkondiging buite die eie volksverband bedoel nie.

Dit is goed en wel, maar dan moet 'n paar dinge duidelik onderskei, gedefinieer en gehandhaaf word.

Eerstens moet aangemerk word dat die apostolaat en sending nie sinonieme is nie, maar dat sending 'n komponent van die apostolaat is, soos evangelisasie dit ook is, getuienis teenoor Jode dit ook is, ook die hervorming van Rooms-Katolieke, herwinning van leerdwalendes, verkondiging aan ander godsdienstiges en so meer. Hierdie verskillende komponente vereis wesenlik dieselfde arbeid van die kerk, die apostolére arbeid ofte wel kerstening. Daarom kan van al die komponente as sending gepraat word, majr ter wille van die spesialisasie kan ons intern van sending met betrekking tot die apostolęre arbeidsveld wat nie onder evangelisasie, gesprek, getuienis en so meer ingesluit is nie, praat. Die verskeidenheid komponente vereis dus diversifikasie in benadering en benaming.

Tweedens moet aangemerk word dat evangelisasie volgens hierdie formulering nie onder die pastoraat van die kerk val nie, maar onder die apostolaat. Indien ons se die wese van die kerk is Jesus Christus, want die kerk is immers sy aardse liggaam, en dat die kerk twee wesensfunksies het, die apostolaat en die pastoraat, moet beide wesensfunksies ter wille van effektiewe funksionering duidelik onderskei bly. Beide wesensfunksies pastoraat en apostolaat, wat herleibaar is na die kerk se dissipelskap en apostelskap van Christus, het op mekaar betrekking en is inhoudelik aan mekaar verwant. In die dissipelskap, dit wil sé in die kerk se pastorale, presbiterale en diakonale werk, sit altyd ook die dimensie van die apostelskap maar nie soseer die intensie nie. In die apostelskap van die kerk sit die apostolaatsintensie maar dit vind neerslag in die pastorale, presbiterale en diakonale pastoraat ofte wel kerkstigting.

Indien evangelisasie as 'n apostolaatskomponent geïdentifiseer is, kan die 
onderlinge en gemeentelike opsporing van kerklidmate wat verwaarloos, vergeet, en kerklos is, nie evangelisasie genoem word nie. Evangelisasie is sending: dit is apostolaat, terwyl genoemde opsporing en bearbeiding eerder 'n verwaarloosde tug van die kerk is. Laasgenoemde is in elk geval 'n binnekerklike taak - ook al het die kerk toegelaat dat hierdie deel van die kerk hom buite die kerk bevind. Tussen hierdie deel van die pastoraat en evangelisasie as 'n apostolaatskomponent is daar sekerlik prakties 'n deurskynende grens - maar prinsipieel moet die grens duidelik opgeskerp en gehandhaaf word.

Die Instituut sal algaande saam met Sera ook moet besin oor die beste terminologieë en omskrywing van probleemverskynsels en taakvervullings. Die nodige skakeling met die dissipline Godsdiensfilosofie is hier natuurlik voor-die-handliggend. Om 'n paar probleemvoorbeelde in verband met die terminologie te noem: getuienis, evangelisasie, dissiplinisasie, kerstening, hervorming, herwinning, sending.

Gewoonlik praat ons van die getuienis teenoor die Jode. Dit is 'n baie goeie term. Gesien die Ou-Testamentiese kennis van die Jode en die Nuwe-Testamentiese opdrag aan die kerk teenoor die Jode, is dié term baie goed. Om dit te vervang met gesprek of dialoog of sending sou huidig in stryd wees met die Kerk se opvatting van sy taak teenoor die Jode. 'n Wisselterm vir getuienis sou evangelisasie kon wees. By die Jode - met hulle Ou-Testamentiese kennis - ontbreek hoofsaaklik slegs die blye boodskap dat die Messias gekom het en dat Hy Jesus Christus is.

Omdat ons reeds onder evangelisasie die bearbeiding van buitekerklikes verstaan, moet ons dié term daarvoor behou - omdat dit ook pas. Miskien moet oorweeg word om die pastoraatsdeel ten opsigte van die probleem van kerklosheid 'dissiplinisasie' te noem. Dit gaan hier tog om ontroue verbondsmense weer kerklike dissipline te leer. Dit is meer as dissipline. Dit is ook dissipelskap van Jesus Christus. Daarom word hulle nie net gedissiplineer nie, maar gedissipliniseer. Hierdie pastoraatsarbeid kan 'dissiplinisasie' genoem word. Christianisasie (kerstening) is om die volkome gesekulariseerde 'jong sendingveld' te bearbei. Die term hervorming wat in die Kerkwet gebruik word om die voortdurende hervorming van die volkslewe aan te dui, moet om twee redes anders gebruik word. Eerstens het die politiek van ons dag aan hierdie woord in die konteks van die volkslewe 'n volkome politieke betekenis geheg. Tweedens sou die woord in verbondenheid aan die kerklike Reformasie, beter benut kan word in die raad vir hervorming van Rooms-Katolieke. Net soos dit die Kerk se bedoeling moet wees om die RoomsKatolieke te hervorm, moet die Kerk ook via 'n raad vir die herwinning van leerdwalendes sektariěrs probeer terug bring na die kerk toe. Onder die term sending word dan minder die volledige apostolaat van die Kerk bedoel, maar slegs verwys na die Kerk se taak onder geografies en/of kultureel minder maklik bereikbare sen- 
dinguelde.

Dit is belangrik om daarop te let dat die onlangse Witskrif van die Regering oor verstedeliking meld dat veral wat die Blankes betref, wat grootliks reeds verstedelik is, 'die groei van stedelike bevolking met verloop van tyd toenemend die gevolg van natuurlike aanwas (sal wees)' (Departement $s$ a:3). Evangelisasie, gesien ook in die lig van sekularisasie, sal mettertyd byna 'n uitsluitlike stedelike behoefte wees.

\section{Gedifferensicerde taak}

Wanneer die aandag noukeurig op die taak van Rev gevestig word, kom 'n groot spektrum van gedifferensieerdheid aan die lig. 'n Voorlopige proefanalise bring die volgende itemisering op die agenda:

- Oorsaak en bestaanskenmerk van die jong heidendom.

- Bybelse gegewens in verband met die jong sendingveld.

- Aandeel van die ampsdraers en van die lidmate in die evangelisasie.

- Toerusting van lidmate hiervoor: prediking, katkisasie, toerustingskursusse, Bybelstudie, ensovoorts.

- Koffiekamers vir jeugdiges en/of ander kamers vir ander groepe.

- Die diversiteit van lewensomstandighede van jong heidene: verslaafdes, verarmdes, siekes, wetenskap, tegniek, armoede, kapitalisme, ensovoorts.

- Hulpmiddele soos: oudivisuele middele, televisie, radio, telefoonnoodlyne, lektuur, korrespondensie (kursusse), ensovoorts.

- Arbeid onder immigrante, gevangenes, en so meer.

Raad vir kerstening van die volkslewe (Rkv)

Immigrantebearbeiding kan ook hier ressorteer. Maar die arbeid onder gevangenes, wat die bearbeiding van lidmate van die Kerk in gevangenisse is, hoort by die pastoraat van die Kerk.

Om die kersteningproses in al die sfere van die volkslewe te laat invloei, sou in hierdie verband veral aandag aan die owerheid, plaaslik, streek en nasionaal gewy moet word.

Nie net lidmate van die Kerk wat bestuursposisies in owerheidinstansies beklee, moet voorwerp van die Rkv se doelwit wees nie. Elke lidmaat wat die owerheid vorm, moet eintlik 'n subjek en komponent van die Rkv wees terwyl die betrokke owerheid in geheel die objek is.

Die teologiese agtergrond van so 'n Rkv moet in die volkskerkbenadering gevind word. 


\section{Rand vir die herwinning van leerdwalendes (Rhld)}

Om bloot op die hoogste vlak met ander denominasies geleerde gesprekke te voer, is 'n noodsaaklike ekumeniese bedrywigheid. Uit 'n apostolaatsoogpunt gesien, is dit egter nie genoeg nie. Die bestryding van leerdwalings is 'n belangrike pastoraatsaksie - veral in 'n preventatiewe sin. In die apostolaat gaan dit om die herwinning van persone self - die leerdwalendes.

Hierdie apostolaatsfunksie is 'n aktuele diens vanuit die eenheid van die kerk wat 'n cenheid in waarheid is.

Elke gemeente weet hoe die leerdwaalverskynsel in 'n baie groot verskeidenheid geweldige afmetings aanneem. Dit is prakties nie moontlik nie en ook nie in ooreenstemming met die akademiese aard van die formele opleiding van predikante om hulle in die finesse van alle sektes te onderrig nie.

Die Instituut moet nie alleen die nodige lektuur aan gemeentes oor dwaallerings voorsien nie. In hierdie opsig is daar deur Kital in die jongste verlede reeds 'n groot diens verrig. Daarby moet egter ook lektuur in korrekte vorm (byvoorbeeld pamflette, vlugskrifte, traktate, korrespondensiekursusse) voorsien word met die sektariěrs self as lesersteiken. Kassette, video's en ander media moet oorweeg word.

Voortdurende toerustingskursusse om op gemeentelike vlak effektief te opereer, moet aangebied word. Gemeentelede moet nie alleen kundig onderlê word in die belydenis van die Kerk nie, maar ook in die kuns van gesprekvoering in hierdie verband sodat die leerdwalendes gewin kan word.

Die Instituut moet 'n katalisator wees om uiteindelik 'n verskeidenheid apostolaatsdiẹnsgroepe in die gemeentes toerustend te bereik.

\section{Raad vir hervorming van Rooms-Katolieke (RhRK)}

Dit is te negatief om te praat van die bestryding van die Roomse gevaar of sektariese invloede. Sprinkane word effektief bestry - of muskiete, vlieẽ en insekte, maar sektes vereis ook positiewer optrede.

Die Hervormde Kerk het sy bestaan te danke aan die hervorming van die deel van die Rooms-Katolieke Kerk. Dit kom dus uit ons eksistensie dat ook ons ons ontstaan moet voortsit.

Die persentasie Roomses in ons midde, Blank en Swart, bied 'n groot arbeidsveld: $9,4 \%$ van blanke stedelike gebiede, $3,5 \%$ van blanke plattelandse gebiede, $11,4 \%$ van Kleurling stedelike gebiede, 5,9\% van Kleurling landelike gebiede, 2,7\% stedelike Indiěrs, 1,5\% landelike Indiërs, $11 \%$ stedelike Swartes en 3,8\% landelike Swartes. 
Indien ons in gedagte hou hoe die Rooms-Katolieke Kerk in verhouding tot die Protestantse Kerke in lande soos byvoorbeeld Belgie, 'n daaglikse stryd met plakkate, lektuur, byeenkomste, en so meer het, is dit ter wille van die suiwerheid van die evangelie noodsaaklik dat daar in Suid-Afrika betyds effektief kerklike hervormingsprosesse ten opsigte van die Roomse dwalings geïnisieer en gehandhaaf sal word.

Veral die Swartes, met die tradisionele voorvaderaanroeping en hulle voorliefde vir ritusse en seremonies, is 'n maklike voedingsveld vir die Roomse Kerk.

In die gees van die hervorming van Martin Luther en Johannes Calvyn is dit tog sending by uitnemendheid om die suiwere Woord soos 'n klippie in die dam van die onkundige mensdom te gooi. Die rimpels bereik die verste walle. Hierdie klippie moet ook voortdurend weer in die Rooms-Katolieke dam beland.

Gespesialiseerde aandag moet te midde van 'n ongesonde gees van ekumenisme gekontinueerd aan die hervorming van Rooms-Katolieke gegee word. Studie van die taak, metodebeplanning, toerusting, begeleiding en lektuurvoorsiening (gepaardgaande ook met Bybelverspreiding), is voor-die-hand-liggende diensterreine van die Instituut.

\section{Rasd vir Bybetverspreiding en kolportasie (RBk)}

Daar kan geen faset van die apostolaat sonder die Bybel uitgevoer word nie. By elke faset speel bykomende paslike lektuur in ons tyd van geletterdheid 'n ontsaglike rol. Selfs wanneer 'n persoon nie persoonlik bereik kan word nie, is sy posadres of sy publieke verskyning nog altyd 'n apostolaatskanaal.

Bepaalde samewerking met die Bybelgenootskap is vanselfsprekend. Gemeentelike kolporteurs sal benewens periodieke toerusting ook voortdurende begeleiding, aanmoediging, advies en hulp kan ontvang. Gesien die groot gebrek aan leeslus, veral wat goeie en spesifiek kerklike lektuur betref, is dit 'n dringende behoefte dat die Kerk voldoende voltydse toegeruste persone benoem om te kolporteer.

Raad vir getuienis teenoor die Jode (Rg)

Nie alleen die uitdruklike opdrag van die Bybel om spesifiek die Jode te evangeliseer nie, gesien teen die agtergrond van die besondere situasie van die Joodse gelowige, maar ook die feit dat ons Jode in ons onmiddellike leefwerreld het, maak die getuienis teenoor die Jode aktueel. Van alle Blankes in Suid-Afrika is 2,6\% Jode. Dit mag miskien min klink maar as ons dit vergelyk met $2,8 \%$ Gereformeerdes en 5,4\% Hervormdes, maak hulle tog 'n beduidende statistiese werklikheid.

Dit is nie alleen nodig dat die Kerk se studie oor hierdie saak in die verlede georden en benut word nie, maar die belangrike situasie van die Jode moet nog 
grondig en deeglik voortgesit word. Dit word gestaaf deur die feit dat die Kerk tot nou toe self nog nie formeel duidelikheid oor die situasie het nie. Dit blyk uit die hantering van die hele saak in die Agenda van die Algemene Kerkvergadering, 1986, bladsye 117 en 118. Waar die Raad vir Arbeid onder die Jode (tans die Raad vir Godsdienste) die situasie in vier alternatiewe modelle opsom en dan kies vir een, verskil die Kommissie van die Algemene Kerkvergadering in die finale maak van 'n keuse vir 'n model. Die Raad se mening is ook dat hy nie die getuienisarbeid self hoef te inisieer of hoef te implimenteer nie, maar dat dit op die weg van die Raad vir Evangelisasie is. Ook hier verskil die Kommissie van die Raad.

Dit is dus duidelik dat skakeling van betrokke rade, soos voorgestel in Sera, en aktivering van navorsing, toerusting en opleiding nodig is.

Nie net die situasie van die Joodse gelowiges, gesien die konteks van Ou en Nuwe Testament, moet bestudeer word nie, maar die nuanses van die getuienis self moet uitgepluis word. Behalwe die opskrifstelling van wat nodig is, moet die kommunikasiepunte en gespreksinhoude uitgesorteer word.

Die feit dat baie Joodse gelowiges nie biologiese nageslag van die Jode is nie en die feit dat sommige Christene die Joodse geloof aanneem, moet in die hele proses onder die loep kom. Die Jode en Christene se samewerking in die huidige Israelistaat, byvoorbeeld by wyse van die sogenaamde Christen Ambassade in Jerusalem, waarby byvoorbeeld vooraanstaande Afrikaanse politieke figure van ons land en leraars van Afrikaanse kerke by betrokke is, moet aandag ontvang. Selfs 'n Joodse getuienisprojek via Joodse Christene van Suid-Afrika in Suid-Afrika en in die Israelistaat, kan oorweeg word. In hierdie verband kan ook kennis geneem word dat 'n Jood sy burgerskap in die Israelistaat verbeur wanneer hy 'n Christen word (Die Kerkblad 1990:14).

Omdat die Jode hoofsaaklik geleerde en vooraanstaande mense van ons gemeenskap is, moet gesofistikeerde metodes ondersoek word. 'n Mens sou vra of 'n publikasie met die tema: Die Joodse Christus vir die Jode (The Jewish Christ for the Jews'), nie vir 'n beginpunt al 'n goeie wegspring kan wees nie? Maar dit beboort alles eers deur die Instituut, vir sover dit ingebed is in Sera, sistematies uitgesorteer te word.

Om dit alles in goeie perspektief te bestudeer sou nie alleen die godsdiens van die Ou-Testamentiese gelowige bestudeer moet word nie, nie alleen die Nuwe Testament se siening van die Joodse gelowiges nie, maar ook die huidige gestaltes van die Joodse geloof in ons land, sal deeglik nagevors moet word.

Raad vir sending onder swart volke (Rssv)

Dit is nie korrek om te dink dat enige werk onder Swartes, byvoorbeeld ekonomiese 
bystand, sosiale opheffing, opvoedkundige dienste, hospitalisasie en so meer, sending is nie. Dit is 'n ou en uitgediende koloniale opvatting. Gewoonlik het dit berus op 'n verwesteringsproses wat onder die naam van sending eerder 'n kultuuroordrag was. Hiermee saam moet ons ook wegkom van die gedagte dat sending net onder Swartes gedoen kan word. Ook die gedagte dat swart volke die heidenvolke is, is nie meer in ooreenstemming met die werklikheid nie. Die volgende syfers uit die 1980-sensus toon dat slegs Venda in ons onmiddellike omgewing oorwegend uit nie-Christene bestaan: Venda 62,3\%, Gazankulu 59,7\%, Lebowa 47,7\%, Kwazulu $27,9 \%$, Ka-Ngwane 24,8\%. Transkei $25 \%$, Ciskei $16,4 \%$, Kwa-Ndebele $15,4 \%$, Qwa-qwa 12\%, Bophuthatswana 5,2\%. Oor ons hele geografiese omgewing is slegs 23\% van alle mense nie-Christene. Ons Christendom onder alle Swartes beslaan 74,1\% terwyl die grootste groep Christene (?) onder alle Swartes aan die onafhanklike kerke behoort, naamlik 29,3\%. Die tweede grootste is die Rooms- Katolieke 9,9\% en dan die Metodiste 9,2\%. Die NO Kerk volg met 6,5\% (HSRC Report 1985:20).

Hieruit is dit baie duidelik dat ons nie meer die swart volke alleen as enigste en sonder meer as sendingterrein moet beskou nie. Omdat die kwaliteit van die Christendom inderdaad in ' $n$ groot mate onder die Swartes bevraagteken moet word, moet ons bestaande sendingprojekte onder hulle voortgaan en uitbrei.

Daarom kan ons huidige Sendingraad en sy samestelling min of meer met superintendent, Hervormde Teologiese Opleiding (HTO), ringsendingrade en so meer, net so behoue bly. Saam met die kleiner aanpassings aan die bestaande strukture, behoort daar egter ook ernstige aandag aan die beter en vloeiender funksionering daarvan gegee te word. Miskien moet oorweeg word dat die Sendingraad net een maal in se drie jaar vergader, maar dan oor 'n langer tyd as 'n halwe dag en met 'n volledige, grondige en doelgerigte agenda. Gedurende die jare waarin die Sendingraad nie vergader nie, moet 'n uitgebreide dagbestuur sake behartig en onder andere saam met die dosente op 'n rotasiestelsel die ringsendingraadvergaderings bywoon.

Om meer effektief te wees kan die Instituut wat die Rssv betref, op die meer genoemde terreine van navorsing, toerusting en opleiding ontsaglike hulpdiens verrig.

\section{Raad vir verkondiging aan ander godsdienstiges (Rvag)}

Soos reeds aangetoon, is Vendaland as 'n eenheid die naaste grootste sendingveld. Die grootste sendingveld in ons onmiddellike omgewing, afgesien van swart volke, is waarskynlik die Indiërgemeenskap. Hulle teenwoordigheid in Natal stoot die persentasie nie-Christene in Natal die hoogte in, naamlik $38,9 \%$ van alle mense. In 
ander provinsies is die getal nie-Christene ten opsigte van alle mense: Kaap $13,2 \%$ OVS $10,6 \%$, Transval $19,2 \%$.

Die Indiërbevolking is in totaal $87,5 \%$ nie-Christene. Hier het ons statisties gesproke dus die allergrootste sendingveld wat ons onmiddellike omgewing betref. Reeds in 1945 is op ons Algemene Kerkvergadering gepleit dat daar aandag aan hierdie terrein gegee moet word. Ook die huidige politieke ontwikkeling bring hierdie sendingveld as ' $t$ ware in die kamer langs ons of by ons.

Omdat nie alle Indiërs Moslems is nie, 'n verkeerde persepsie wat in 'n groot mate by baie mense heers, sou 'n raad vir arbeid onder Moslems nie die beste wees nie. Slegs $18,8 \%$ Indiërs is Moslems, terwyl $62,4 \%$ Hindoes is.

\section{Navorsing toerusting en opleiding}

Rvag sou via die Instituut dus nie alleen navorsingsprojekte moet loods oor die bestudering van die betrokke tradisionele godsdienste onder ons swart volke nie, maar ook die bestudering van die plaaslike Hindoe- en Moslemgodsdienste. Wat eersgenoemde betref, sou die Instituut as diens, veral deur die Instituut se navorsingsresultate, vir Rvag protytlik wees.

Onder 'ander godsdienste' moet hier dus veral verstaan word alle godsdienste wat vir ons hier van belang is, uitgesonderd in ' $n$ mindere mate die tradisionele godsdienste en in meerdere mate die Joodse godsdiens. 'Ander godsdienste' sou dus hoofsaaklik Hindoeïsme en veral akuut die Islam, wees.

Die navorsing sou met betrekking tot al die aktuele godsdienste moet plaasvind. Die huidige Kital met sy ekumeniese biblioteek is 'n goeie vertrekpunt. Die toerusting en opleiding van die Instituut sou via Rvag, ten opsigte van sy afdeling, hoofsaaklik die Hindoe- en Moslemveld in die oog hê.

Omdat die Moslems en Hindoes in ons land oor die algemeen beskaafde, geleerde en vermoẻnde mense is, sal in die beplanning en toenusting van kersteningsarbeiders (miskien deeltydse werkers eers?) baie gesofistikeerd te werk gegaan moet word. Die vind en opleiding van gewese Hindoes en Moslems moet aandag geniet.

Miskien moet die kerstening hier 'n proses van literatuurvoorsiening, gepaardgaande of beginnende met Bybelverspreiding, aanneem. Onderrig in die gesprekvoering met hierdie mense sou uiters nodig wees. Hoe moet so 'n Christen uit die ander godsdienste verder in die Kerk begelei word? Waarheen met hom? Verwys ons hulle na 'n bestaande Christelike kerk of stig ons 'n eie Indiērkerk - wat die voor-die-hand-liggende is?

Die studie van genoemde godsdienste le natuurlik op die weg van die Godsdienswetenskap. Omdat ons midde in hierdie godsdienste staan, waar 'n kerste- 
ningstaak vervul moet word, vereis ons situasie deeglike navorsing wat ook prakties georiēnteer moet word. Dit is duidelik dat een of twee Godsdienswetenskaplikes, wat voltyds in die akademie staan, dit nie alleen kan behartig nie. Dit vereis grondige praktiese teenbeplanning van ons.

Om die opdrag aan die Raad vir Arbeid onder die Jode maar net uit te brei sodat dit die studie van genoemde godsdienste insluit, is volkome onprakties. Eers word 'n Raad wat reeds weens deeltydse aandag sy oorspronklike taak van arbeid onder die Jode self nie uitvoer nie, verder belas. Tweedens is daar 'n totale verskil tussen die Joodse godsdiens en die Islam en die Hindoeïsme. Daar moet gedifferensieer word.

Die Instituut kan navorsingskakeling opbou met ander inrigtings wat die navorsing oor hierdie godsdienste kan bevorder. Voorbeelde daarvan is ASRSA (Association for the Study of Religion in South Africa) en veral met die oog op praktiese sending onder Moslems: Life Challenge, Posbus 273, Claremont 7735.

Behalwe die genoemde godsdienste, leef ons in ' $n$ wèreld waar sekere ideologieě soos godsdienste word - en sekere godsdienste soos ideologieë. Wat eersgenoemde betref, kan ons aan samelewingsteologieë, tydsgeesteologieë en sosialistiese teologiez soos die Swart Teologie, die Teologie van Bevryding en die Teologie van die Revolusie dink. In die navorsing hiervan kan die Instituut ook skakeling met die oog op inligting opbou met vele instansies. Om een te noem: Serkos - Sentrum vir Reformatoriese en Kontemporêre Studies.

Die Raad vir Ekumeniese Sake hou in noue verbintenis met Kital hom reeds besig met die bestudering van hierdie ideologieë. Dit is ook ' $n$ formele opdrag van die Kerk. Die resultate van hierdie navorsing sou egter effektief aangewend kan word wanneer die Instituut met sy ingebedheid in Sera die praktiese teikens identifiseer. Grondige, suiwere en koersgewende vorming van studente by Hervormde Teologiese Opleiding ten opsigte van die ideologiese gevare, beplande voorligting in Montshafatsi, voorligting tydens alle kerklike vergaderings, korrespondensiekursusse hieroor en so meer, is voorbeelde van wat in 'n strategie vir ons te doen staan.

Dit is vanselfsprekend dat in hierdie situasie die superintendent van die Rssv 'n wakker oog sal he, 'n op datum kundigheid en 'n onverslapte aktiewe ywer. Aan al hierdie komponente kan die Instituut 'n groot diens van toerusting lewer.

\section{Raad vir ekumeniese arbeid (Rea)}

Hierdie Raad behoort nie net hom besig te hou met 'n neutrale begrip ekumeniese 'sake' nie. Gesien vanuit die apostolaat het Rea positief arbeid om te verrig. Hierdie arbeid sluit getuienis in, maar ook allerlei ander vorme van bystand. 
Veral die besluit van die Algemene Kerkvergadering dra 'n duidelike apostolaatsarbeid op aan hierdie raad:

Die Raad vir Ekumeniese Sake verleen alle moontlike hulp aan onafhanklike kerke en kerkgenootskappe om die teologiese kwaliteit van die opleiding en vorming van dienaars van die Woord vir dié kerke te bevorder. Dié hulp geskied deur middel van daadwerklike hulp met die handboeke en handleidings vir die studie, indiensopleiding van dienaars van die Woord en voorsiening van leesstof vir ampsdraers en lidmate steeds in samewerking met en op versoek van die betrokke kerke.

(NHKA 1986:219)

Rea sal ten opsigte van hierdie taak as lid van Sera en met behulp van Kital sy arbeid strategies en effektief moet beplan en uitvoer. Die kwaliteit Christenskap van die $74 \%$ Christene onder Swartes in Suid-Afrika, waarna voorheen verwys is, kan op hierdie wyse verbeter word.

Verder het Rea sy gewone taak op grond van ons Kerk se eie ekumeniese beleid. Hierdie gewone taak moet egter ook effektief gestroomlyn word. Daarby moet ons ekumeniese beleid steeds in die regte bane ontwikkel. Hierby kan die volgende opmerkings gemaak word.

Die katolisiteit van die kerk is in sy apostolisiteit geleë - dat hy ingaan in die verskeidenheid van die volke van die hele wêreld. Die katolisiteit van die kerk sê dus dat dit 'nie geleë (is) in, gebonde (is) aan of bepaal (is) tot 'n sekere plek of sekere persone nie, maar dit is versprei en verstrooi oor die hele wêreld. Tog is dit met hart en wil saamgevoeg en verenig in een en dieselfde Gees, deur die krag van die geloof (NGB, art 27).

Omdat die kerk van Jesus Christus kragtens sy katolisiteit wat dus uit sy apostolositeit spruit, een en dieselfde roeping oral ter wêreld het, het verskillende kerkorganisasies, aanvanklik op die sendingterrein en later op die grotere wêreldterrein, mekaar se hande gevat om daardeur effektiewer kerk te wees. Hierdie aksie word die ekumene genoem. Dit is ook 'n openbaring van die eenheid van die kerk.

Almal wat deur die geloof in Christus ingelyf is, moet ook op makrovlak in broederlike liefde een liggaam wees. Ons moet dit ook nie alleen met woorde nie, maar ook met die daad teenoor mekaar bewys (Diensboek 1987:72). 
Ongelukkig het ekumeniese bewegings algaande momentum en teologie van hulle eie verkry en dikwels in 'n rigting beweeg waar die ekumene nie meer 'n openbaring is van 'n samevoeging met hart en wil, verenig in dieselfde Gees deur die krag van die geloof nie. In plaas hiervan het ekumeniese liggame eie stoom en teologie as samevoeging van geld en planne, verenig in dieselfde humanisme deur die krag van die sinkretisme, verkry.

Weens die wesenlike goeie van die ekumene, soos dit aanvanklik ten dienste van die katolisiteit en daarmee die apostolisiteit van die kerk wou strek, moet ons Kerk deel hé aan die ekumene. Ter wille van organisasie en strategie, wat magtige moderne verskynsels is, kan die Kerk byna nie anders as om ekumenies bedrywig te wees nie. Maar ten opsigte van die afwykings van die ekumene, soos hierbo vermeld, het ons Kerk 'n standpunt ingeneem met betrekking tot die vorm van ekumeniese verbintenisse.

Die een vorm van ekumene is lidmaatskap aan 'n ekumeniese liggaam. So 'n lidmaatskap vereis finansiële steun, morele bevordering, gekompromitteerde teologie en al die praktiese implikasies wat daaruit voortvloei. Vanweë die geskiedenis van ekumeniese bewegings word hierdie vorm, dié van lidmaatskap aan 'n ekumeniese liggaam, deur ons Kerk in ons tyd afgewys (vgl ook Van der Westhuizen 1977:58-67).

Die ander vorm van ekumene om direkte kontak of bilaterale en gekwalifiseerde verbintenis met ' $n$ kerkorganisasie aan te knoop, is onses insiens deesdae 'n effektiewer aksie omdat die waarheid van die evangelie minder bedreig en meer tot verkondiging kom.

Die Nederduitsch Hervormde Kerk van Afrika sou op laasgenoemde wyse dalk te vinde kan wees vir byvoorbeeld 'n Suid-Afrikaanse forum vir reformatoriese kerke (SAfork)/South African forum of reformed churches (SAforc). So 'n raad mag geen doelstelling wat bots met die kerke op hom verteenwoordig, daarstel nie. Slegs doelstellings van die betrokke kerke mag ter wille van organisatoriese en strategiese effektiwiteit in sy funksie geïnorporeer word. Ook mag dit geen algemene fonds genereer nie. Fondse wat vir spesifieke uitgawes waarop gesamentlik besluit word benodig word, moet elke keer van die verteenwoordigende kerke per hulle eie besluit verkry word.

\section{BISKIKBAARHEID VAN ARBEIDSKRAG}

Behalwe die toerusting van bestaande arbeidskrag, soos tot nou elke keer aangedui is, bted die moontlike oorskot van predikante 'n groot potensiaal binne die verband van die sogenaamde 'tentmakersberoep' of deeltydse dienswerk. 
Fundamenteel behoort ons, behalwe die reorganisasie van bestaande strukture ook alles in werking te stel om sowel die Nederduitsch Hervormde Kerk van Afrika as die Hervormde Kerk in Suidelike Afrika op lidmatevlak missioner te orienteer. Hier le die grootste taak.

Elke gelowige het vanweë die priesterskap van die gelowiges 'n missionêre of kersteningshand. Aan hierdie hand sit die volgende vyf vingers.

Eerstens is elke gelowige 'n kersteningsfakkel deur die Woord van die lewe uit te dra (Fil 2:15). Om met integriteit 'n gelowige te wees, is om orals en altyd 'n brandende fakkel te wees - aangesteek deur die Woord en Gees van God. Buite die geloof in Christus om, leef die mens immers in 'n donker wereld. Christus moet met alle mense gekommunikeer word. Ons huismense, huisbediendes, tuinbediendes, handelaars, medemens, sport, werksituasie, politiek, almal en alles wat in die kamer van ons bestaan leef, moet onder die lig van ons geloofslewe kom. 'n Mens steek tog nie lamp op en sit dit onder 'n emmer nie maar op 'n staander, en dit gee lig vir almal in die huis (Matt 5:15). Driekwart van alle Swartes wat in ons land is, behoort wel tot 'n kerk maar die kwaliteit Christenskap is in baie gevalle onder verdenking.

Tweedens moet elke gelowige priesterlik met sy gebede vir die saak van die kerstening intree (Ef 6:18, 19; 2 Tess 3:1). Soos elke gelowige en nie net sekere sendingvriende nie 'n brandende lig moet wees, so moet ook elke gelowige bid dat die Woord van die Here vinnig mag versprei en oral oorwin.

Derdens moet studente en werkers vir die kersteningstaak geïdentifiseer en gewerf word (Hand 13:1-3). Daarvoor moet met huisbesoek en in ander gesprekke or die Hervormde Kerk se kersteningsbeleid en die fokus op die Hervormde Teologiese Opleiding gehandel word.

Vierdens het die kerk vir sy gang na die wêreld finansies of materièle ondersteuning nodig. So is Paulus dankbaar dat die kerk in Filippi 'n aandeel aan sy rekening van inkomste en uitgawes gehad het (Fil 4:15, 16). Behalwe dat die Nederduitsch Hervormde Kerk vir die kersteningstaak se vaste uitgawes begroot, is daar verskeie uitgawes of fondse waarvoor fondsinsamelings by wyse van pinksterkollektes, dankoffertoedelings en spesiale pogings geloods kan word. By die Hervormde Teologiese Opleiding alleen bestaan onder andere byvoorbeeld die $\mathrm{CH}$ Rautenbach-merietefonds, H P Wolmarans-sendingpublikasiefonds, die $\mathbf{J} \mathbf{G} \mathbf{d u}$ Plessis-biblioteekfonds en die HTO-uitbreidingsfonds.

Vyfdens is voortgangshulp aan ander wat direk met die georganiseerde sending te make het, nodig. Gaius het dit gedoen en Johannes spreek sy waardering daaroor uit en roep Gaius tot volharding daarin op: 
Help hulle asseblief vir hulle verdere reis op 'n wyse soos God dit verwag, want hulle is op reis om Christus te verkondig, en hulle ontvang niks van die heidene nie. Dit is dus ons plig om sulke mense te onderhou, sodat ons daardeur ons deel kan bydra tot die verspreiding van die waarheid.

'n Infrastruktuur vir hierdie voortgangshulp waarin elke gelowige betrokke kan wees, is gemeentelike kersteningsgroepe, ringsraadbetrokkenheid, režlmatige verrykende studie, gesprekke, beplanning en inisiěring van projekte: nie net na buite die kerk soos Jode, Roomses, sektes, Moslems, Hindoes, Swartes en so meer nie, maar ook hoe om die missionere dimensie van die kerk na binne te versterk. Gelowiges kan kersteningswerkers leer ken en waardeer ( $3 \mathrm{Joh}$ 1:5-7), en verheug wees oor resultate: Die mense vertel self hoe julle ons ontvang het en hoe julle julle van die afgode tot God bekeer het en nou die lewende en ware God dien (1 Tess 1:9).

Kerstening is uiteindelik nie net 'n saak van definisie, akademie en die verstand nie. Dis 'n saak van geloof; van die hart en van die hand van elke gelowige.

\section{Literatururverwysings}

Die Departement van Staatkundige Ontwikkeling en Beplanning s a. Witskrif oor Verstedeliking. Pretoria.

Die Kerkblad, Maart 1990, bl 14.

Hervormde Kerk in Suidelike Afrika 1985. Notule van die derde Algemene Kerkvergadering. Umgababa, Natal.

Human Sciences Research Council Report 1985. Religion, intergroup, relations and social changes in South Africa. Pretoria: HSRC.

Nederduitsch Hervormde Kerk van Afrika, 1986a. Agenda van die Algemene Kerkvergadering. Pretoria.

- 1986b. Notule van die Algemene Kerkvergadering. Pretoria

- 1986c. Herderlike skrywe aan die gemeentes van die Nederduitsch Hervormde Kerk van Afrika. Pretoria: Gutenberg.

- 1987. Diensboek, Formulier vir die bediening van die Nagmaal. Pretoria: Kital.

- 1985. Kerk en wêreld 2000. Pretoria: Kital.

- 1989. Kerkwet en bepalings. Pretoria: Gutenberg.

Van der Westhuizen, H G 1977. Vertrou op God. Pretoria: HAUM.

- 1978. Pleit vir Sinto. Die Hervormer, Augustus 1978.

Wiersinga WA, 1977. s v Evangelisatic. Christelijke Encyclopedie. 